\title{
Behavioral teratogenicity induced by maternal food restriction: maternal cannibalism and poor reflex development in offspring
}

\author{
Esther Lopes Ricci \\ Maria Martha Bernardi \\ Silvana Lima Górniak \\ Helenice Souza Spinosa * \\ University of São Paulo \\ Department of Pathology, School of Veterinary Medicine and Animal Science \\ Avenida Prof. Orlando Marques de Paiva, 87, CEP 05508-000, São Paulo - SP, Brazil \\ * Author for correspondence \\ hspinosa@usp.br
}

Submetido em 18/03/2013

Aceito para publicação em 13/01/2014

\section{Resumo}

Teratogenicidade comportamental induzida pela restrição alimentar materna: canibalismo materno e mau desenvolvimento reflexológico da prole. Estudos recentes têm atribuído a presença de vários produtos químicos tóxicos durante a gestação à desnutrição materna. Um déficit no estado nutricional materno pode ser fundamental para o desenvolvimento de teratogenicidade. Entretanto, na atualidade, o conceito de teratogênese não se restringe a anomalias estruturais, mas, também, a mudanças funcionais, como, por exemplo, aquelas observadas no comportamento. Este estudo investigou os efeitos da restrição alimentar (RA) materna durante a gestação sobre o desenvolvimento físico, comportamental e reflexológico da prole. Ratas prenhes foram submetidas a restrição de ração em diferentes níveis $(15,40,55$ e $70 \%$ do consumo diário de ração em comparação ao grupo controle), com início no dia de gestação 6 (DG6) até o DG17; o grupo controle recebeu ração ad libitum. Após o nascimento, o desenvolvimento físico e neurocomportamental da prole foram avaliados. Os resultados mostraram que, com exceção da redução de peso, o desenvolvimento físico das proles dos grupos RA não diferiu do grupo controle. No entanto, os grupos experimentais apresentaram déficits de reflexos neurológicos, particularmente na geotaxia negativa e no reflexo palmar. Na atividade geral, a prole do RA 40\% (E40) e do E55 apresentaram baixas frequências de locomoção e levantar e longos períodos de imobilidade. Os resultados mostram que RA materna durante a gestação promove desordens neurológicas na prole, mas não afeta o desenvolvimento físico, evidenciando a importância das avaliações comportamentais.

Palavras-chave: Canibalismo; Desenvolvimento da prole; Restrição alimentar materna; Teratogenicidade

\section{Abstract}

Recent studies have attributed the presence of several toxic chemicals during pregnancy to maternal malnutrition. A deficit in maternal nutritional status may be crucial for the development of teratogenicity. However, nowadays, the concept of teratogenesis is not restricted to structural abnormalities, but, also, to functional changes, such as, for instance, those observed in behavior. This study investigated the effects of maternal food 
restriction (FR) during pregnancy on the physical, behavioral, and reflex development of offspring. Pregnant female rats underwent feed restriction at different levels $(15,40,55$, and $70 \%$ of the daily feed intake when compared to the control group), starting on gestation day 6 (GD6) until GD17; the control group received food ad libitum. After birth, the physical and neurobehavioral development of offspring were assessed. The results showed that, except for weight reduction, the physical development of offsprings from the FR groups did not differ from that of the control group. However, the experimental groups showed deficits in neurological reflexes, particularly with regard to negative geotaxis and palmar reflex. In general activity, the offspring of the FR group 40\% (E40) and E55 showed low frequencies of locomotion and rearing and long periods of immobility. The results show that maternal FR during pregnancy promotes neurological disorders in offspring, but it does not affect physical development, showing the importance of behavioral assessments.

Key words: Cannibalism; Maternal food restriction; Offspring development; Teratogenicity

\section{Introduction}

Maternal food restriction (FR) during pregnancy may induce several outcomes at maternal and fetal levels. At the maternal level, an increased frequency of cannibalism was observed after maternal FR. This phenomena was attributed as part of an organized mechanism that balances litter size with metabolic energy supply (DESANTIS; SCHMALTZ, 1984; SCHNEIDER; WADE, 1989). However, maternal nutritional deficits (BÃ, 2013), as well as maternal stress (PEDERSEN et al., 1991; PINTO; SHETTY, 1995), can lead to pup-killing behavior. Besides, an increased risk of adverse health outcomes in adult offspring was observed (RASMUSSEN, 1998; BERGMANN et al., 2008; KUMON et al., 2010; ZHANG et al., 2010; LAPORTE-BROUX et al., 2012). Studies in the two last decades have shown that maternal nutrition status may be critical for pup development (DING et al., 2010; ZHANG et al., 2010; LABORIE et al., 2011). Nutrient restriction during early fetal and embryonic development has long-lasting consequences for the offspring, including decreased birth weight, altered fat metabolism (BELLINGER et al., 2006), hypothalamic-pituitaryadrenal axis reactivity (LESAGE et al., 2006; MACRÌ; WÜRBEL, 2006), abnormal muscle structure and function (FAHEY et al., 2005), decreased reproductive performance (CHERNOFF et al., 2009), and behavioral effects (KUMON et al., 2010; ZHANG et al., 2010). Impairment in female reproduction caused by metabolic deficiencies include sexual behavior/libido deficits, delayed sexual maturation, acyclicity, amenorrhea, and anovulation (CHERNOFF et al., 2009). However, teratogenesis is not restricted to structural abnormalities, but it may also result in an abnormal development of the fetus, including fetal malformation, growth retardation, damage to the development, behavioral changes, and even death (HANSEN; YANKOVITZ, 2002).

In animal models, nutrient restriction during the perinatal period exerts a strong influence on brain structure, physiology, and biochemistry and it can even lead to permanent brain damage (MORGANE et al., 2002; LIANG et al., 2007). Although brain development continues into adulthood and the micronutrient status can influence functioning beyond infancy, rapid growth rate of the brain during the last third of pregnancy and the early postnatal stage makes it particularly vulnerable to an inadequate diet over these periods (BENTON, 2010). The developing brain is particularly susceptible to the intrauterine environment and nutrition plays a critical role in the maturation and functional development of the fetus central nervous system (WARNER; OZANNE, 2010). Previous studies have shown that prenatal or perinatal nutrient restriction impairs the hippocampal synaptic plasticity and it adversely affects hippocampaldependent learning and memory tasks; these impairments start in the postnatal period and they continue into adulthood (AUSTIN et al., 1986; DWYERA et al., 2011). Maternal food deprivation (at the level of $50 \%$ ) has also disrupted the physical and neurobehavioral development of rat pups (ZHANG et al., 2010).

Toxicological studies have attributed various toxic effects to FR. Despite evidence that energy 
status during pregnancy critically affects reproductive success and offspring development, the literature has limitations and gaps. The purpose of this study is assessing the effects of maternal FR during pregnancy on rat pups at birth and many days after. The physical and neurobehavioral development of pups was assessed by means of a standard neuroteratogenic protocol, in order to better understand the role played by body weight in toxicological studies.

\section{Materials and Methods}

\section{Animals}

Fifty-six female rats, obtained from our own colony, were mated with previously tested fertile male rats (2 females to 1 male in each cage). The onset of pregnancy was confirmed by the observation of spermatozoa in vaginal smears (gestation day 0 ). The pregnant females were individually housed in plastic cages $(32 \times 40 \times 18$ $\mathrm{cm})$ at a controlled temperature $\left(22 \pm 2^{\circ} \mathrm{C}\right)$ and humidity level (65-70\%) and under artificial light exposure (12 h light/12 h dark cycle, with light from 6:00 a.m.). Female rats also had free access to Nuvilab ${ }^{\circledR}$ rodent chow (Nuvital company, São Paulo, Brazil) and filtered water. Animals were kept in accordance with the guidelines of the Committee on Care and Use of Laboratory Animal Resources from the School of Veterinary Medicine and Animal Science of University of São Paulo, Brazil (Protocol 1,462/2008).

\section{Food restriction and food intake measurements}

Thirty-six pregnant females were divided into five groups. In the control group, animals received feed ad libitum. In the 4 other groups, animals underwent various FR levels: 15\% (E15), 40\% (E40), 55\% (E55), or $70 \%(\mathrm{E} 70)$ of the total amount eaten by the control individuals. FR occurred from gestation day 6 (GD6) to GD17 and food intake was measured $( \pm 0.1 \mathrm{~g})$ from GD6 to GD20.

After delivery, 8 pups ( 4 male and 4 female) were left with their mothers until weaning. On postnatal day 1
(PND1), all litters were externally examined and sexed. The pups were weighed at 1,7,14,21, 28, and 35 days of life. During the lactation period, the physical and reflex development of pups and their open-field activity were assessed.

\section{Physical development}

Every day, from PND1, the following physical parameters of pups were observed: lower appearance, pinna detachment, hair growth, incisor eruption, opening of the ear canal, eye opening, testes descent, and vaginal opening (ALDER; ZBINDER, 1977).

\section{Reflex and neurobehavioral development}

The following reflex tests were performed: surface righting reflex (time to return to a normal ventral position after positioning the pup on its back - this test was performed from PND5); palmar reflex (number of pups who closed the palm of their front paw when it was touched - this test was performed from PND2); and negative geotaxis (time to turn at least $90^{\circ}$ after being positioned face down on a platform that is inclined $45^{\circ}$ - this test was performed from PND5). Moreover, the general activity of pups was measured for 3 minutes every day from PND15 to PND20, in an open field, according to a procedure described by Schwarz et al. (2003). The open field was a round wooden arena painted in black and it is $40 \mathrm{~cm}$ in diameter, with the floor divided into 25 plots. The field was illuminated with a $40 \mathrm{~W}$ light bulb suspended over the center (55 lux). Hand-operated counters and stopwatches were employed to score locomotion frequency (number of floor units entered with all 4 paws), rearing frequency (number of times the animal stood on its hind limbs), immobility duration (total number of seconds without movements) and number of fecal boluses. To minimize the potential effects of circadian changes on open-field behavior, we alternated the testing of control and experimental groups. The open-field device was washed with a $5 \%$ ethanol/ water solution between testing sessions, in order to avoid possible bias due to odors left by previous animals. 


\section{Statistical analysis}

The results were expressed as the mean \pm SEM. Homoscedasticity was checked by means of the F test. Normality was checked through KolmogorovSmirnov test. The number of pups born in the control and experimental groups was analyzed with a one-way ANOVA followed by Duncan post hoc test. Openfield data and physical and reflex development data were analyzed with a two-way ANOVA followed by Bonferroni post hoc test. A linear correlation test assessed the correlation between cannibalism and FR. In all cases, the results were regarded as significant if $\mathrm{p}<0.05$.

\section{Results}

Figure 1 shows the number of pups born per female and postpartum maternal cannibalism. One-way ANOVA revealed significant differences between groups concerning the number of pups born $(\mathrm{F}(4 / 4555)=3.62$, $\mathrm{p}=0.012$ ). Moreover, there is a positive correlation between the degree of cannibalism and FR $(r=0.955, p$ $=0.014)$ : maternal cannibalism rises as dietary restriction is increased, and up to $100 \%$ cannibalism was observed in female rats in the group E70.

As the number of pups in the group E70 was reduced due to maternal cannibalism, this group was not observed for physical and behavior development.

Figure 2 shows the body weight and reflex activity of pups (on PND7, PND14, PND21, PND28, and PND35). Two-way ANOVA revealed significant differences in body weight between groups, with varying levels of FR $(\mathrm{F}(3 / 180)=0.48, \mathrm{p}<0.0001)$ on different days $(\mathrm{F}(4 / 180)=98.61, \mathrm{p}<0.0001)$. Two-way ANOVA also revealed a significant interaction between the factors group and day $(\mathrm{F}(12 / 180)=0.33, \mathrm{p}<0.0001)$. Compared to the control group, the body weight of pups in all experimental groups on PND35 was lower ( $<<$ 0.05). In addition, pups in the group E55 had a lower body weight on PND14 and PND28 ( $<<0.05)$. No significant differences were observed between groups for the physical parameters lower appearance, pinna detachment, hair growth, incisor eruption, opening of the ear canal, eye opening, testes descent, or vaginal opening (data not show).

FIGURE 1: Number of pups born and percentage of cannibalism by female rats with food restriction at 15\% (E15), 40\% (E40), 55\% (E55), or 70\% (E70) of the total amount eaten by control individuals. $\mathrm{N}=10$ dam/group. *p $<$ 0.05 , one-way ANOVA followed by Bonferroni test.

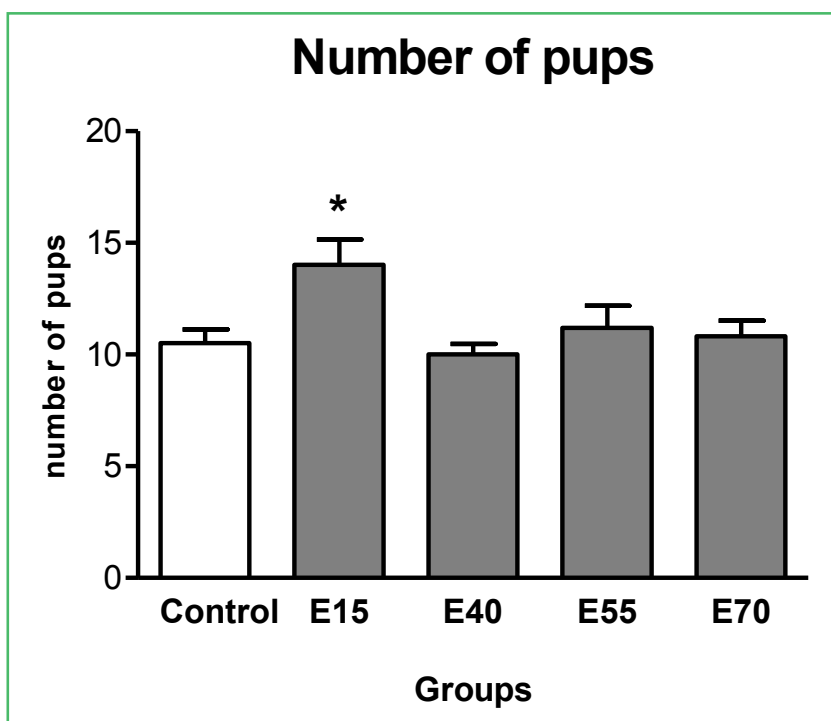

Canibalism

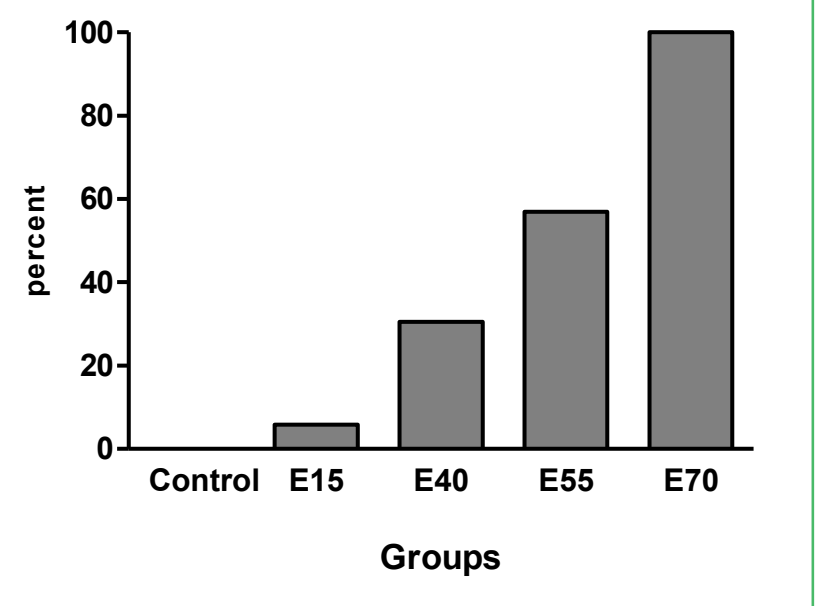

Data for palmar reflex in two-way ANOVA revealed a significant difference between experimental treatment $(\mathrm{F}(3 / 144)=43.27, \mathrm{p}<0.0001)$, days $(\mathrm{F}(3 / 144)=31.66$, $\mathrm{p}<0.0001)$ and a significant interaction between factors $(\mathrm{F}(9 / 144)=18.68, \mathrm{p}<0.0001)$. Compared to the control group, rats in groups E40 and E55 had a slower palmar reflex on PND4 and PND4. On PND6, the number of pup rats in E40 exhibiting the palmar reflex was lower. 
In contrast, the group E15 on PND6 still had a faster reflex than the control group. On PND10, all pups in the experimental groups had lost this reflex.

FIGURE 2: Body weight, negative geotaxis, and palmar grasp reflexes of pup rats with food restriction at $15 \%$ (E15), $40 \%$ (E40), or $55 \%$ (E55) of the total amount eaten by the control individuals. $\mathrm{N}=8$ pups/group. ${ }^{*} \mathrm{p}<0.000$, two-way ANOVA followed by Duncan post hoc test.

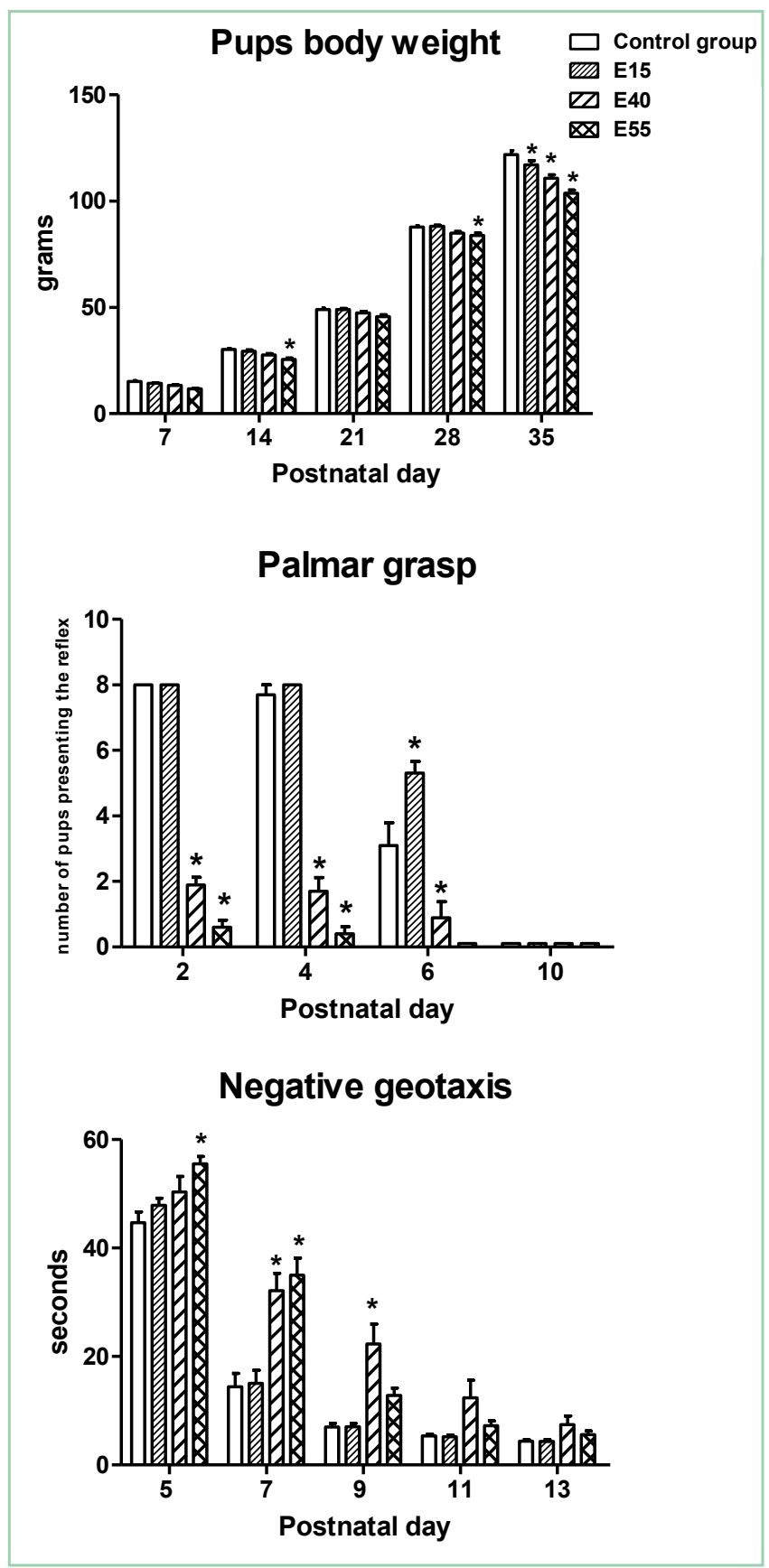

The negative geotaxis reflex observed from PND5 to PND13 in pups from FR groups. Two-way ANOVA revealed a significant difference between treatments $(\mathrm{F}$ $(3 / 180)=5.66, \mathrm{p}<0.0001)$ and days $(\mathrm{F}(4 / 180)=79.97$, $\mathrm{p}<0.0001)$. The interaction between factors was also significant $(\mathrm{F}(12 / 180)=3.70, \mathrm{p}<0.0001)$. On PND5, the reflex time of E55 rat pups was greater than that of the control group. On PND7, the reflex time of E40 and E55 rat pups was greater than that of the control group. On PND9, only E40 rat pups had greater reflex times than control individuals. No significant differences were observed between groups in the surface righting reflex (data not shown).

The effects of FR on the open-field activity are shown in Figure 3. Two-way ANOVA revealed significant differences in locomotion frequency according to treatment $(\mathrm{F}(3 / 216)=397.64, \mathrm{p}<$ $0.0001)$ and day $(\mathrm{F}(5 / 216)=347.51, \mathrm{p}<0.0001)$. The interaction between factors was also significant $(\mathrm{F}(15 / 216)=18.26, \mathrm{p}<0.0001)$. Compared to the control group, there was a decreased locomotion frequency from PND16 to PND20 in E55 rat pups and on PND18 and PND20 in E40 rat pups. There were no differences between control individuals and E15 rat pups. Regarding the rearing frequency of FR pups in the open field, two-way ANOVA revealed significant differences between treatment groups $(\mathrm{F}(3 / 216)=53.23, \mathrm{p}<0.0001)$ and day $(\mathrm{F}(5 / 216)$ $=31.02, \mathrm{p}<0.0001)$. There was also a significant interaction between the two factors $(\mathrm{F}(15 / 216)=3.05$, $\mathrm{p}=0.0002)$. Compared to the control group, E15 rat pups reared less frequently on PND17; E40 and E55 rat pups reared less frequently from PND16 to PND20. Regarding immobility duration observed in the open field, two-way ANOVA revealed a significant difference between treatment groups $(\mathrm{F}(3 / 216)=1,086.82$, $\mathrm{p}<$ $0.0001)$ and days $(\mathrm{F}(5 / 216)=3,975.44, \mathrm{p}<0.0001)$. The interaction between factors was also significant $(\mathrm{F}$ $(5 / 216)=38.95, p<0.0001)$. The multiple comparison tests reveal greater immobility periods in the groups E40 and E55 when compared to the control group on all PNDs. In contrast, individuals from the group E15 had an increased immobility only on PND17. 
FIGURE 3: Open-field behavior of pup rats with food restriction at $15 \%(\mathrm{E} 15), 40 \%(\mathrm{E} 40), 55 \%(\mathrm{E} 55)$, or $70 \%(\mathrm{E} 70)$ of the total amount eaten by the control individuals. $\mathrm{N}=8$ pups/group. ${ }^{*} \mathrm{p}<0.0001$, two-way ANOVA followed by Bonferroni test.
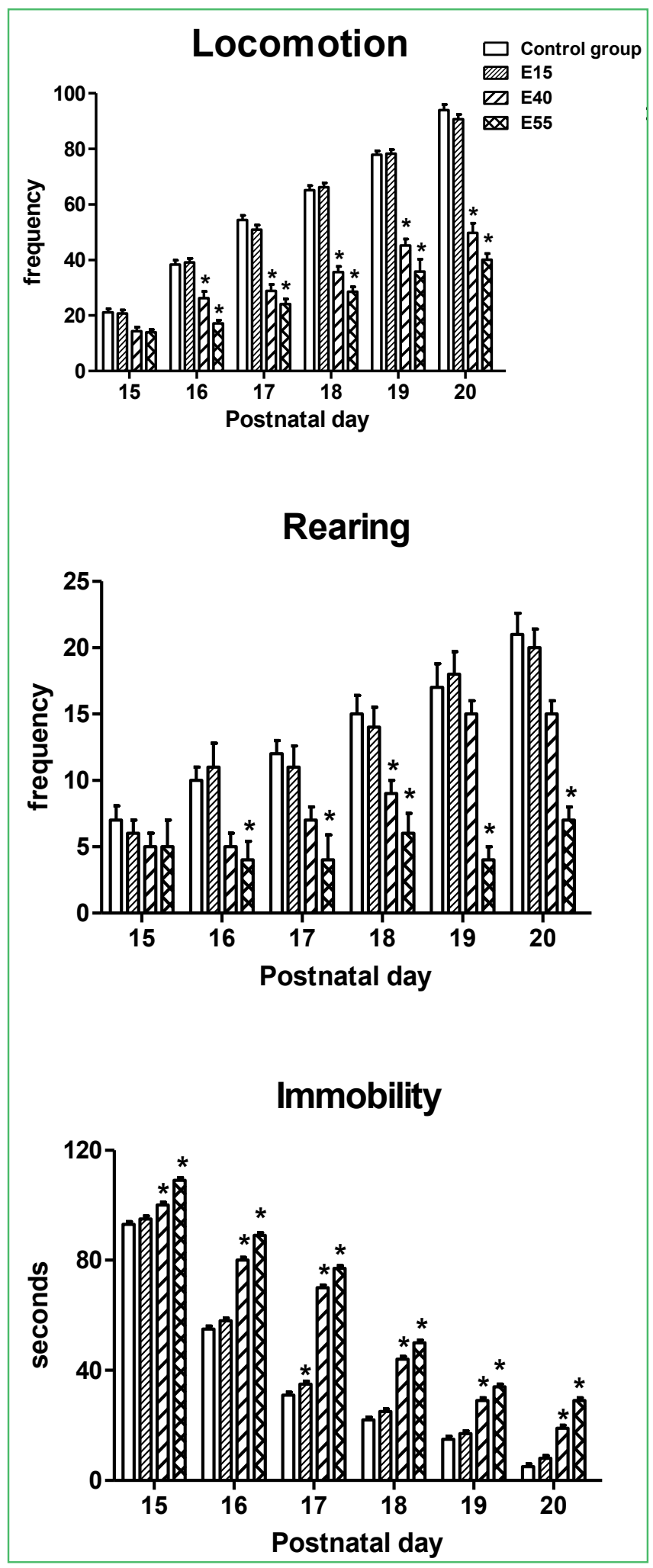

\section{Discussion}

These results demonstrated that food restriction and maternal cannibalism at birth are related. The experimental group that underwent the greatest dietary restriction (E70) was also the group showing the highest cannibalism. Among the pups that survived maternal cannibalism during breastfeeding, only the group E55 showed a decreased weight on PND14. Although the other parameters of physical development tested were not altered by maternal food deprivation, the neurological reflexes of animals were affected. General activity as measured in the open field was also decreased in E40 and E55 rat pups.

Regarding maternal cannibalism, the mother that underwent the greatest FR killed and ate all its pups soon after birth. There are at least two possible explanations for this cannibalism. One possibility is that the decreased supply of nutrients during pregnancy creates a greater need for protein, increasing the likelihood that the mother eats its offspring in order to obtain protein. A second possibility is that the stress caused by FR over pregnancy causes neuronal alterations that lead the mother to kill and eat its offspring soon after birth. Because of this cannibalism, it was not possible to assess the physical parameters of offspring among E70 mothers. It has been established that maternal cannibalism can occur when the offspring manifests physical impairments. In this study, we could not determine the presence of impairments among the pups that were cannibalized, but current experiments in our lab have explored this possibility (DIPE, 2009). This study showed that teratogenic indices in pups from FR mothers (E40, E55, and E70) included decreased birth weight, an increased proportion of dead fetuses one hour after birth, and an increased number of fetuses with kinked ureters. No malformations serious enough to threaten the life of fetuses were observed. Dipe (2009) also investigated the immunological deficits produced by FR. It was concluded that FR during organogenesis does not promote structural malformations, but it does lead to offspring with lower birth weight and significant immunological changes. Thus, factors other than 
teratogenesis may have contributed to the maternal cannibalism rate observed in this study.

The pups that survived cannibalism were weighed at 7, 14, 21, 28, and 35 days of life. During breastfeeding, only E55 pups had a decreased weight on PND14. Pups started eating over the 10 days of breastfeeding, thus the decreased weight observed on PND14 in the group E55 may be a consequence of the mother's FR. After breastfeeding, on PND35, all pups had a decreased weight, suggesting that FR had a long-term effect on the pups' body weight. The other parameters of physical development were not altered by food deprivation.

There were evident deficits in neurological reflexes, particularly with regard to negative geotaxis and palmar reflex. Reflexes allow a pup to respond to its environment in a specific, predictable, and involuntary way. Reflexes are instinctive and serve to protect the pup. All pups are born with identical reflexes.

The palmar reflex, also named Babinski reflex, occurs in normal children under 2 years of age and it disappears as the child grows and the nervous system develops (SINGERMAN; LEE, 2008). In children older than 2 years, the presence of Babinski reflex indicates damage to the nerves that connect the spinal cord to the brain (the corticospinal tract). Babinski reflex can occur either in the left or right side of the child or in both sides. An abnormal Babinski reflex can be temporary or permanent (WALKER, 1990). In this study, we observed that the number of E40 and E55 pups with Babinski reflex was lower than that of the control group on PND2, 4, and 6; E15 pups had an increased reflex on PND6. On the last day of observation, Babinski reflex was absent in pups from all groups. These results demonstrate an early disappearance of the reflex in E40 and E55 pups. Regarding negative geotaxis, E55 pups had greater negative geotaxis than the control pups on PND5 and 7, while E40 pups showed an increased negative geotaxis on PND7 and 9. The negative geotaxis reflex is involved in the animal's spatial orientation, more specifically in the spatial map in adult animals (FOX, 1965). Therefore, this study showed that FR during pregnancy changes the spatial abilities of offspring.
There were no differences between the experimental and control pups either in the startle reflex or in the onset of walking, suggesting that FR during pregnancy did not affect offspring's sensory and motor abilities.

The spontaneous motor activity observed in the open field determined animals' ability to move around an unknown area regardless of environmental stimuli. This test is used to check an animal's emotionality, exploration pattern, and motor behavior. A significant decrease in locomotion and rearing frequency was observed in the groups E40 and E55, in addition to increased immobility periods. Bernardi and Palermo-Neto (1983) showed that the striatal dopaminergic system is closely associated with decreased locomotion and rearing frequencies, as well as with increased immobility. This study suggests that maternal FR during pregnancy, at the 40 and 55\% levels, affects the development of their pups' motor activity.

Moreover, our results showed that the degree of maternal FR affects the neurobehavioral development of offspring, although some behavioral parameters can recover over time.

\section{Acknowledgements}

This research was funded by grants from the Research Support Foundation of the State of São Paulo (FAPESP) and the National Council for Scientific and Technological Development (CNPq). It was developed from the MS dissertation of the first author, submitted to Graduate Program in Experimental and Comparative Pathology of University of São Paulo.

\section{References}

ALDER, S.; ZBINDER, G. Methods for the evaluation of physical, neuromuscular and behavioral development of rats in early postnatal period. In: NEUBERT, D.; MERKER, H. J.; KWASIGROCH, T. E. (Ed.). Methods in prenatal toxicology. Stuttgart: Thieme, 1977. p. $175-185$.

AUSTIN, K. B.; BRONZINO, J.; MORGANE, P. J. Prenatal protein malnutrition affects synaptic potentiation in the dentate gyrus of rats in adulthood. Brain Research Bulletin, Amsterdam, v. 394, p. 267-273, 1986.

BÃ, A. Perinatal thiamine deficiency-induced spontaneous abortion and pup-killing responses in rat dams. Nutritional Neuroscience, 
Philadelphia, v. 16, n. 2, p. 69-77, 2013.

BELLINGER, L.; SCULLEY, D. V.; LANGLEY-EVANS, S. C. Exposure to undernutrition in fetal life determines fat distribution,locomotor activity and food intake in ageing rats. International Journal of Obesity, London, v. 30, p. 729-738, 2006.

BENTON, D. Neurodevelopment and neurodegeneration: are there critical stages for nutritional intervention? Nutrition Reviews, Malden, v. 68, n.1, p. 6-10, 2010.

BERGMANN, R.; BERGMANN, K.; DUDENHAUSEN, J. Undernutrition and Growth Restriction in Pregnancy. Nestle Nutrition Workshop Series. Paediatric Programme, Vevey, v. 61, p. 103-121, 2008.

BERNARDI, M. M.; PALERMO-NETO, J. Effects of apomorphine administration on rearing activity of control and experimental rats with drawn from long-term haloperidol treatment. General Pharmaceutical Journal, New York, v. 14, p. 545-547, 1983.

CHERNOFF, N.; GAGE, M. I.; STOKER, T. E.; COOPER, R. L.; GILBERT, M. E.; ROGERS, E. H. Reproductive effects of maternal and pre-weaning undernutrition in rat offspring: age at puberty, onset of female reproductive senescence and intergenerational pup growth and viability. Reproductive Toxicology, Louisville, v. 28, n. 4, p. 489-494, 2009.

DESANTIS, D. T; SCHMALTZ, L. W. The mother-litter relationship in developmental rat studies: cannibalism versus caring. Developmental Psychobiology, San Diego, v. 17, n. 3, p. 255-262, 1984.

DING, F.; LI, H. H.; LI, J.; MYERS, R. M.; FRANCKE, U. Neonatal maternal deprivation response and developmental changes in gene expression revealed by hypothalamic gene expression profiling in mice. PLoS ONE, Cambridge, v. 5, n. 2, p. 94-102, 2010.

DIPE, V. V. Effects of maternal feed restriction in Wistar rats offspring: evaluations by classical and immunoteratology protocols. 2009. 124 f. Dissertação (Mestrado em Patologia) Universidade de São Paulo, São Paulo. 2009.

DWYERA, C.; CATHY, M.; CHRISTINE, M.; MOINARDA, C.; KIRSTIN, M.; MCILVANEYA, K. M.; MORGANA, C. A.; BÜNGERA, L. The effect of gestational undernutrition on maternal weight change and fetal weight in lines of mice selected for different growth characteristics. British Journal of Nutrition, Cambridge, v. 105, p. 539-548, 2011.

FAHEY, A. J.; BRAMELD, J. M.; PARR, T. The effect of maternal undernutrition before muscle differentiation on the muscle fiber development of the newborn lamb. Journal of Animal Science, Champaign, v. 83, p. 2564-2571, 2005.

FOX, W. M. Reflex-ontogeny and behavioral development of the mouse. Animal Behaviour, St Andrews, v. 13, p. 234-241, 1965.

HANSEN, W. F.; YANKOVITZ, J. Pharmacologic therapy for medical disorders during pregnancy. Clinical Obstetrics and Gynecology, Salt Lake City, v. 45, n. 1, p. 136-152, 2002.

KUMON, M.; YAMAMOTO, K.; TAKAHASHI, A.; WADA, K.; WADA, E. Maternal dietary restriction during lactation influences postnatal growth and behavior in the offspring of mice. Neurochemistry International, Philadelphia, v. 57, n. 1, p. 43-50, 2010.

LABORIE, C.; MOLENDI-COSTE, O.; BRETON, C.; MONTEL, V.; VANDENBULCKE, V.; GRUMOLATO, L.;
ANOUAR, Y.; VIEAU, D. Maternal Perinatal undernutrition has long-term consequences on morphology, function and gene expression of the adrenal medulla in the adult male rat. Journal of Neuroendocrinology, v. 23, p. 711-724, 2011.

LAPORTE-BROUX, B.; ROUSSEL, S.; PONTER, A. A.; GIGER-REVERDIN, S.; CAMOUS, S.; CHAVATTE-PALMER, P.; DUVAUX-PONTER, C. Long-term consequences of feed restriction during late pregnancy in goats on feeding behavior and emotional reactivity of female offspring. Physiology \& Behavior, Cincinnati, v. 106, n.2, p. 178-184, 2012.

LESAGE, J.; SEBAAI, N.; LEONHARDT, M. Perinatal maternal undernutrition programs the offspring hypothalamo-pituitaryadrenal (HPA) axis. Stress, London, v. 9, p. 183-198, 2006.

LIANG, H.; XIONGA, W.; ZHANG, Z. Effect of maternal food restriction during gestation on early development of F1 and F2 offspring in the rat-like hamster (Cricetulus triton). Zoology, Jena, v. 110, p. 118-126, 2007

MACRÌ, S.; WÜRBEL, H. Developmental plasticity of HPA and fear responses in rats: a critical review of the maternal mediation hypothesis. Hormones and Behavior, Atlanta, v. 50, n. 5, p. $667-$ 680, 2006.

MORGANE, P. J.; MOKLER, D. J.; GALLER, J. R. Effects of prenatal protein malnutrition on the hippocampal formation, Neuroscience \& Biobehavioral Reviews, Oxford, v. 26, 471-483, 2002.

PEDERSEN, C. A.; CALDWELL, J. D.; MCGUIRE, M.; EVANS, D. L. Corticotropin-releasing hormone inhibits maternal behavior and induces pup-killing. Life Sciences, Columbus, v. 48, n. 16, p. 1537-1546, 1991.

PINTO; M. L.; SHETTY, P. S. Influence of exercise-induced maternal stress on fetal outcome in Wistar rats: inter-generational effects. British Journal of Nutrition, Southampton, v. 73, n. 5, p. 645-653, 1995.

RASMUSSEN, K. M. Effects of under- and overnutrition on lactation in laboratory rats. Journal of Nutrition, Cambridge, v. 128, p. 390-393, 1998.

SCHNEIDER, J. E.; WADE, G. N. Effects of maternal diet, body weight and body composition on infanticide in Syrian hamsters. Physiology \& Behavior, Cincinnati, v. 46, n. 5, p. 815-821, 1989.

SCHWARZ, A.; GÓRNIAK, S. L.; BERNARDI, M. M.; DAGLI, M. L. Z.; SPINOSA, H. S. Effects of Ipomoea carnea aqueous fraction intake by dams during pregnancy on the physical and neurobehavioral development of rat offspring. Neurotoxicology and Teratology, Oxford, v. 25, p. 615-626, 2003.

SINGERMAN, J.; LEE, L. Consistency of thr Babinski reflex and its variants. European Journal of Neurology, London, v. 15, n. 9, p. 960-964, 2008.

WALKER, H. K. The plantar reflex. In: WALKER, H. K.; HALL, W. D.; HURST, J. W. (Ed.). Clinical methods: the history, physical, and laboratory examinations. Chapter 73. 3 ed. Boston: Butterworths, 1990. p. 125-148.

WARNER, M. J.; OZANNE, S. E. Mechanisms involved in the developmental programming of adulthood disease. Biochemical Journal, London, v. 427, p. 333-347, 2010.

ZHANG, Y.; LI, N.; ZHANG, T.; YANG, Z. Effects of maternal food restriction on physical growth and neurobehavior in newborn Wistar rats. Brain Research Bulletin, Amsterdam, v. 83, p. 1-8, 2010. 